\title{
Computed tomography based staging in the carcinoma of the larynx
}

\author{
Sarita Magu*, Mona Bhatia*, Daya Shankar Mishra*, Vivek Kumar Kaushal**, Manav Rakshak**, Vikas Kakkar ${ }^{\S}$
}

\begin{abstract}
Abstrak
Karsinoma laring mewakili kira-kira sepertiga dari keganasan leher dan kepela dan merupakan satu diantara keganasan yang paling sering di India. Untuk mengevaluasi peranan CT scan dalam proses "staging" karsinoma laring, dua puluh penderita telah dipelajari. Semua penderita adalah laki-laki dengan rata-rata usia 54 tahun. Laringoskopi langsung dan tidak langsung memberi hasil 1) tumor glotis (55\%) dan 9 tumor supraglotis (45\%). Secara histologis, semua tumor berjenis karsinoma skuamosa. Staging klinis dan CT dilakukan berdasarkan kriteria AJCC 1988. CT upstaging terjadi pada 13 kasus (65\%). Beberapa invasi tumor hanya terdeteksi dengan CT: daerah tiroaritenoid (55\%) pasca laring (50\%), di bawah pita suara (45\%), sinus piriformis (35\%), komisura anterior $(25 \%)$, invasi kartilago (25\%), daerah preepiglotis (20\%), pasca krikoid (15\%), komisura posterior (15\%) dan subglotis (10\%). Keterlibatan kelenjar getah bening terdeteksi pada tiga penderita (15\%).
\end{abstract}

\begin{abstract}
Carcinoma of the larynx represents approximately one third of all head and neck cancers and is amongst the commonest head and neck malignancy in India. In order to evaluate the role of computed tomography in staging laryngeal carcinoma, twenty consecutive patients of subsequently proved carcinoma of the larynx were recruited in this study. All the patients were males with avarage age of 54 years. Indirect and direct laryngoscopy revealed 11 tumours to be glottic (55\%) and 9 tumours to be supraglottic (45\%). Histologically, all tumours were squamous cell carcinomas. The clinical and CT staging was done according to AJCC 1988 staging system. CT upstaging of the carcinoma occurred in 13 cases (65\%). Certain invasions were detected only on CT: thyroarytenoid space (55\%) paralaryngeal space (50\%), undersurface of true vocal cords $(45 \%)$, pyriform sinus (35\%), anterior commissure (25\%), cartilage invasion (25\%), pre-epiglottic space (20\%), post cricoid (15\%), posterior commissure (15\%) and subglottic extension (10\%). Lymph node involvement was detected in three patients (15\%).
\end{abstract}

Keywords: Laryngeal carcinoma, computed tomography, larynx, CT staging.

Carcinoma of the larynx represents approximately one third of all head and neck cancers. ${ }^{\text {' Almost all }}$ malignancies of the larynx arise from the mucosal surface and thus are accessible to direct visualization and biopsy. The radiologist evaluates areas that the clinician cannot see, such as areas deep to the mucosa or blocked from direct visualization by the bulk of the tumour. ${ }^{2}$ The goal of the radiologic study is to help determining the most appropriate therapy. Modern laryngeal imaging uses either computed tomography (CT) or magnetic resonance (MR) imaging to show

* Department of Radiodiagnosis, Pt. B.D. Sharma PGIMS, Rohtak - 124001, Haryana, India

"Department of Radiotherapy, Pt. B.D. Sharma PGIMS,

Rohtak - 12400I, Haryana, India

\$ Department of E.N.T., Pt. B.D. Sharma PGIMS,

Rohtak - 124001, Haryana, India the relationship of disease to the very small laryngeal structures. Even in patients who cannot co-operate completely, CT offers a consistently good examination, with short imaging times and thin section. ${ }^{2}$ Better geometric delineation of the anatomy of the larynx is likely to improve staging and radiation treatment of the carcinoma of the larynx as compared to clinical staging, especially for supraglottic and glottic cancers. ${ }^{3,4,5}$

This study was undertaken to assess the role of computed tomography based staging for the staging of carcinoma of the larynx.

\section{METHODS}

The study comprised 20 patients who attended otorhinolaryngeal Outpatients Department with suspected growth of the larynx. All the patients were 
examined clinically, including indirect laryngoscopy and had $\mathbf{M}_{0}$ disease. Direct laryngoscopy was undertaken in all patients and clinical staging was done. Radiological examination included radiography of the neck and chest soft tissue and contrast enhanced computerised tomography (CT). CT was done on Shimadzu SCT 3000 TF scanner. Sections were obtained parallel to the laryngeal ventricle as seen on lateral scout view with the patient in the treatment position. If the ventricle was not identified, CT gantry angle was adjusted so that the scan beam was parallel to $\mathrm{C}_{5}-\mathrm{C}_{6}$ intervertebral disc space. Scans were obtained in quiet breathing from lobule of the ear to the manubriosternal junction. Five millimeters thick sections were taken with additional $2 \mathrm{~mm}$ sections at the level of vocal cords. 2-D reconstruction in sagittal and coronal planes were done using computer assisted functions to see the extent of the tumour. The staging was done according to AJCC 1988, staging system.

\section{RESULTS}

The present study comprises 20 patients, previously untreated and histopathologicaaly proved squamous cell carcinoma of the larynx. All the patients were males with the mean age at presentation of 54 years. Thirteen patients $(65 \%)$ were aged between 41-60 years. Fifteen patients $(75 \%)$ were admitted within four months of the onset of the first symptom. Hoarseness $16 / 20(80 \%)$ was the main presenting symptom, the other were stridor $7 / 20$ (35\%) and dysphagia $5 / 20(25 \%)$.

Indirect and direct laryngoscopy revealed 11 tumours to be glottic $(55 \%)$ and nine tumours. to be supraglottic (45\%) (Table 1 and 2). Table 3 shows the comparative clinical/CT staging of the tumour. A total of nine $(45 \%)$ cases of carcinoma of the glottis were upstaged. One case of $T_{1}$, carcinoma of the glottis was upstaged to $T_{2}$ status; two cases of $T_{2}$ and six cases of $\mathrm{T}_{3}$ carcinoma of the glottis were upstaged to $\mathrm{T}_{4}$ status. At the supraglottic site, CT upstaging of the primary lesion was seen in four (20\%) cases. One case of $\mathrm{T}_{2}$ and $T_{3}$ each and both cases of $T_{2}$ status were upstaged to $\mathrm{T}_{4}$ status. On clinical evaluation, only seven (35\%) cases found to be staged correctly when compared with $\mathrm{CT}$ staging. All were squamous cell carcinoma of owhich $35 \%$ were well differentiated, $55 \%$ were moderately differentiated, while $10 \%$ were poorly differentiated.
Clinical examination of the cervical lymph nodes revealed two patients with $\mathrm{N}_{2}$ status and one case with $\mathrm{N}_{3}$ status. On CT staging, three cases were detected as having occult lymph nodes. The overall upstaging was observed in 13 cases $(65 \%)$. Table 4 shows the various tumour invasions detected only on CT and were primarily responsible for the upstaging.

Table 1. Site wise distribution of the T-staging on direct laryngoscopy

\begin{tabular}{lcccccr}
\hline Site & $\mathrm{T}_{1}$ & $\mathrm{~T}_{2}$ & $\mathrm{~T}_{3}$ & $\mathrm{~T}_{4}$ & Total & $\%$ \\
\hline Glottic & 2 & 2 & 6 & 1 & 11 & 55 \\
Supraglottic & 2 & 2 & 1 & 4 & 9 & 45 \\
Subglottic & 0 & 0 & 0 & 0 & 0 & 0 \\
\hline Total no. of cases & 4 & 4 & 7 & 5 & 20 & 100 \\
\hline
\end{tabular}

Table 2. Site wise distribution of the nodal status

\begin{tabular}{lrrrrrr}
\hline Site & $\mathrm{T}_{1}$ & $\mathrm{~T}_{2}$ & $\mathrm{~T}_{3}$ & $\mathrm{~T}_{4}$ & Total & $\%$ \\
\hline Glottic & 10 & 1 & 0 & 0 & 11 & 55 \\
Supraglottic & 7 & 1 & 0 & 1 & 9 & 45 \\
Subglottic & 0 & 0 & 0 & 0 & 0 & 0 \\
\hline Total no. of cases & 17 & 2 & 0 & 1 & 20 & 100 \\
\hline
\end{tabular}

Table 3. Overall staging of the disease

\begin{tabular}{lcccc}
\hline Stage & \multicolumn{2}{c}{ Clinical staging } & \multicolumn{2}{c}{ CT staging } \\
& N & $\%$ & N & $\%$ \\
\hline I & 3 & 15 & 1 & 5 \\
II & 4 & 20 & 0 & 0 \\
III & 7 & 35 & 1 & 5 \\
IV & 6 & 30 & 18 & 90 \\
\hline
\end{tabular}

Total no. of patients

Table 4. Invasions detected only on C.T.

\begin{tabular}{lll}
\hline & $\begin{array}{l}\text { No. of } \\
\text { cases }\end{array}$ & $\%$ \\
\hline Preepiglottic space & 4 & 20 \\
Paralaryngeal space & 10 & 50 \\
Cartilage invasion & 5 & 25 \\
Lymph node involvement & 3 & 15 \\
Thyroarytenoid space & 11 & 55 \\
Pyriform sinus & 7 & 35 \\
Post cricoid region & 3 & 15 \\
Anterior commissure & 5 & 25 \\
Posterior commissure & 3 & 15 \\
Undersurface of true vocal cords & 9 & 45 \\
Extension to subglottic region & 2 & 10 \\
\hline
\end{tabular}




\section{DISCUSSION}

Almost all malignancies of the larynx are squamous cell carcinoma. In our study all the patients were male. A male preponderance has been reported in other studies. ${ }^{8-10}$ Our study revealed that $55 \%$ of the tumours were glottic, which is well documented in literature. ${ }^{9}$ The mean age of the patients was 54 years with $65 \%$ in the age group of $41-60$ years. Hoarseness was the predominant symptom $(80 \%)$. For many years, examination of the larynx was restricted to direct and indirect laryngoscopy, conventional tomography and laryngography. ${ }^{11}$ With the development of better radiation therapy planning and conservative surgery techniques; precise delineation of tumour extent preoperatively by imaging studies and exact staging have become imperative for the appropriate therapeutic planning of laryngeal carcinoma.

CT displays the larynx in a 3-D format allowing direct demonstration of tumour in both the larynx and paralaryngeal soft tissues as well as cartilages. ${ }^{12} \mathrm{CT}$ is more accurate than laryngography in determining superior and inferior limits of the tumour. ${ }^{13}$

In our study, CT upstaging of the carcinoma occurred in $13(65 \%)$ cases. Twelve cases $(60 \%)$, were upstaged to stage IV; $5 \%$ from stage I, $20 \%$ from stage II and $35 \%$ from stage III, while one $(5 \%)$ case was upstaged from stage I to stage III. In $35 \%$ of cases, staging changed from $\mathrm{T}_{3}$ to $\mathrm{T}_{4}$; in $20 \%$ from $\mathrm{T}_{2}$ to $\mathrm{T}_{4}$ status and in $5 \%$ from $\mathrm{T}_{2}$ to $\mathrm{T} 4$. Charlin et a $1^{4}$ have also observed that $\mathrm{CT}$ was most useful in lesions initially classified as $T_{2}$ and $T_{3}$. Sulfaro et al found that $\mathrm{CT}$ has a high overall specificity i.e. $88.2 \%$ but a low sensitivity $(47.1 \%)$.

Clinical and endoscopic evaluation may fail to reveal cartilage invasion. ${ }^{15}$ In our study, cartilage involvement was seen in $25 \%$ cases, not detected clinically. Evidence of cartilage invasion is related to tumour size: lesions greater than $16 \mathrm{~mm}$ lying below the apex of the arytenoid have a high probability of cartilage invasion. ${ }^{16} \mathrm{CT}$ may detect erosion of laryngeal cartilages when sufficiently extensive but microscopic extension cannot be detected. ${ }^{4,5,11,13}$ Tumour extension lateral to the arytenoid cartilage is difficult to assess by laryngoscopy but may be assessed by CT. Widening of the thyroarytenoid space indicates such as an invasion ${ }^{10,11}$ and was seen in $55 \%$ of our cases (Fig.1). Curtin ${ }^{17}$ considered obliteration of fat within or widening of the thyroarytenoid gap on CT as involvement of the pyriform sinus apex.

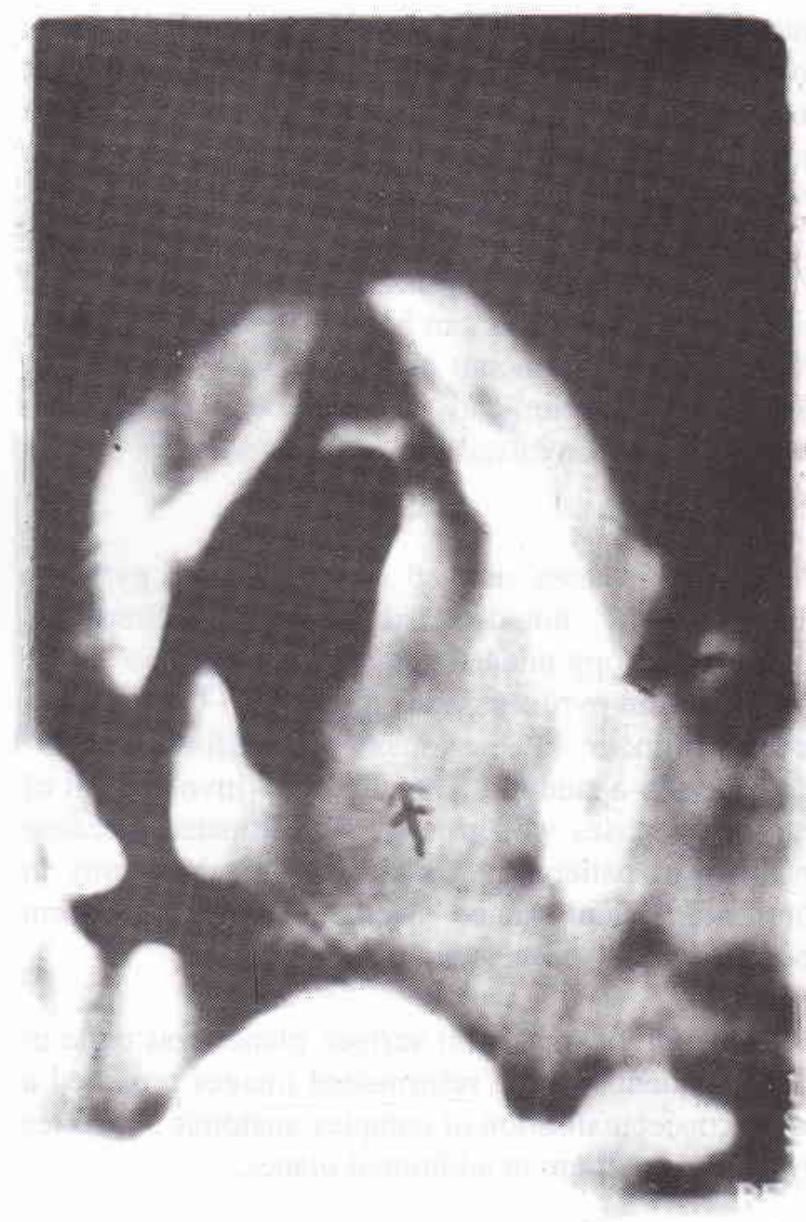

Figure 1. Axial CT (glottic level); growth involving the vocal cord, extension lateral to the arytenoid cartilage, medial displacement of the arytenoid and widened thyro-arytenoid distance. Notice there is also invasion of the thyroid cartilage.

In the present study, two cases (10\%) with subglottic extension were missed clinically. Tumours arising between the true cords and lower border of cricoid are rare. Any soft tissue between cricoid cartilage and airway is abnormal and may represent subglottic tumour extension. ${ }^{18}$ Inferior extension can easily be assessed with either CT or MR imaging. However, MRI does afford the additional perspective of coronal sections. $^{2}$

Involvement of preepiglottic space occurs with supraglottic tumours. The depth of tumour invasion is the most difficult to measure clinically. ${ }^{13}$ In our study, $45 \%$ were supraglottic tumours. In $20 \%$ cases, preepiglottic space involvement was not detected clinically, but was seen on CT. CT is more reliable for estimation of paraglottic space involvement, invasion 
into the preepiglottic space and aryepiglottic fold. ${ }^{13,15,19}$ Detection of this type of invasion is vital for future therapy planning. Preepiglottic space does not contain lymph nodes, but does contain lymphatic channel that allow cervical metastasis. ${ }^{20-22}$

Tumour involvement of tissue deep to anterior and posterior commissures can be detected by CT if there is an increase in amount of tissue and/ or fixation of tissue. The anterior and posterior commissure were found to be involved in $25 \%$ and $15 \%$ cases respectively.

Seven $(35 \%)$ cases showed involvement of pyriform sinuses on CT, not detected clinically. Indirect and direct endoscopy underestimated the extension of the tumour to the pyriform sinus apex while CT correctly reveals tumour at the apex of pyriform fossa. ${ }^{23}$ However, in a study by Duggal et al, involvement of pyriform sinuses was grossly overestimated, because majority of patients had undergone tracheostomy in their study and hence, were unable to perform modified valsalva manoeuvre.

Reformation of images in various planes was done in all the patients. These reformatted images provided a better conceptualisation of complex anatomic structures by displaying them in additional planes.

We conclude that $\mathrm{CT}$ in laryngeal carcinoma, when used to determine tumour extent, has marked impact on accuracy of staging. This is best manifested in displaying deep tumor extension that cannot be seen during evaluation of mucosal surface by laryngoscopy/ endoscopy.

\section{REFERENCES}

1. W.H.O. I.A.R.C. Cancer incidence in five continents. Scientific Publications No.2, Lyon 1982; Vol IV, 390.

2. Curtin HD. Imaging of the larynx: current concepts. Radiology 1989; 173: 1-11.

3. Katsantonis GP, Archer CP, Rosenblum BN et al. The degree to which accuracy of preoperative staging of laryngeal carcinoma has been enhanced by computed tomography. Otolaryngol Head Neck Surg 1986; 95(1): 52-6.

4. Duggal RK, Jain RC, Knadelwal N, Mehra YN, Suri S. Clinical and CT correlation in transglottic tumours of the larynx. Ind J Radiol Imag 1991; 1: 81-5.
5. Sulfaro $\mathrm{S}$, Barzan $\mathrm{L}$, Guerin $\mathrm{F}$ et al. $\mathrm{T}$ staging of the laryngohypopharyngeal carcinoma. Arch Otolaryngol Head Neck Surg 1989; 115;613-20.

6. Beahrs DH. Manual of staging of cancer. $4^{\text {th }}$ ed. JB Lippincott Co., 1992: p. 34-40.

7. Bames L, Gnepp DR. Diseases of the larynx, hypopharynx, and oesophagus. In: Surgical Pathology of the Head and Neck. New York: Dekker, 1985: p. 141-226.

8. Jussawalla DJ, Sathe PV. Cancer incidence in Aurangabad city 1981. Indian Joumal of Cancer 1984; 21(2):55.

9. Powell J, Robin PE. Cancer of head and neck: the present state. In: R. Rhys Evans, Evans R, Robin PE, Fielling JWL, Eds. Head and neck cancer. Tunbridge Wells: Castle Rouse Publications, 1983: p. 3-16.

10. Hiranandani LH. Panel on epidemiology and etiology of laryngeal cancer. Laryngoscope 1975; 85:1197.

11. Phelps PD. Carcinoma of the larynx - the role of imaging in staging and pretreatment assessments. Clinical Radiology 1992;46:77-83.

12. Sagel SS, Aujderheide JF, Aronberg DJ et al. High resolution computed tomography in the staging of carcinoma of the larynx. The laryngoscope 1981;91:292-300.

13. Archer CR, Sagel SS, Yeager VL, Martin S, Friendman WH. Staging of carcinoma of the larynx: comparative accuracy of CT and laryngography. AJR 1981;136:571-5.

14. Charlin B, Brazeau-Lamontange L, Guernier B et al. Assessment of laryngeal cancer: CT scan versus endoscopy. J Otolaryngol 1989;18(6):283-8.

15. Gerristen GJ, Valk J, Van Velzen DJ, Snow GB et al. Computed tomography: a mandatory investigational procedure for $\mathrm{T}$ staging of advanced laryngeal cancer. Clinical Otolaryngol 1986;11:307-16.

16. Archer CR, Yeager VL, Herbold DR. Computed tomography vs histology of laryngeal cancer - their value in predicting laryngeal cartilage invasion. Laryngoscope 1983;93:140-7.

17. Curtin HD. Imaging of the larynx. In Head and Neck Imaging, $2^{\text {nd }}$ Ed. CV Mosby, 1991:593-692.

18. Hoover LA, Calcaterra TC, Walter GA. Preoperative CT scan evaluation for laryngeal carcinoma: correlation with pathological findings. Laryngoscope $1984 \mathrm{Mar}$; 94:310-5.

19. Deschepper C, Casselman J, Vande Voorde W et al. The contribution of $\mathrm{CT}$ to the $\mathrm{T}$ staging of laryngeal carcinoma. J Belge Radiol 1989;72(3):191-7.

20. Clerf LH. The preepiglottic space - its relation to carcinoma of the epiglottis. Arch Otolaryngol 1944; 90:177-9

21. Dayal VS, Bahri H, Stone PC. Preepiglottic space - An anatomic study. Arch Otolaryngol 1972;95:130-3.

22. Lain $\mathrm{KH}$, Wong $\mathrm{J}$. The preepiglottic space in relation to spread of carcinoma of the larynx. Am J Otolaryngol 1983;4:81-91.

23. Saleh EM, Mancuoso AA, Stringer SP. Relative roles of $\mathrm{CT}$ and endoscopy for determining the inferior extent of pyriform sinus carcinoma: correlative histopathologic study. Head and Neck 1993;15:33-52. 